IRA-International Journal of Management \& Social Sciences

ISSN 2455-2267; Vol.06, Issue 03 (2017)

Pg. no. 518-526

Institute of Research Advances

https://research-advances.org/index.php/RAJMSS

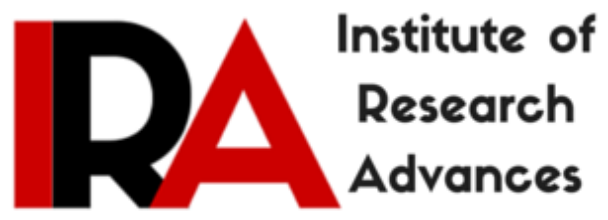

\title{
An Analysis of Public Health Expenditure in Hyderabad Karnataka Region
}

Dr. Basavaraj S Benni

Dean, Social Science

Chairman, Department of Economics

Vijayanagara Sri Krishnadevaraya University, Ballari, India.

\section{Srikara U}

Research Scholar, Department of Economics

Vijayanagara Sri Krishnadevaraya University, Ballari, India.

Type of Review: Peer Reviewed.

DOI: http://dx.doi.org/10.21013/jmss.v6.n3.p17

\section{How to cite this paper:}

Benni, B., \& Srikara, U. (2017). An Analysis of Public Health Expenditure in Hyderabad Karnataka Region. IRA-International Journal of Management \& Social Sciences (ISSN 24552267), 6(3), 518-526. doi:http://dx.doi.org/10.21013/jmss.v6.n3.p17

(C) Institute of Research Advances

(cc) EY-NC

This work is licensed under a Creative Commons Attribution-Non Commercial 4.0 International License subject to proper citation to the publication source of the work.

Disclaimer: The scholarly papers as reviewed and published by the Institute of Research Advances (IRA) are the views and opinions of their respective authors and are not the views or opinions of the IRA. The IRA disclaims of any harm or loss caused due to the published content to any party. 


\section{ABSTRACT}

Health status is the outcome of public spending; Public income is the result of human capital standards in the society. Both influences and complements each other growth. Objective of the study is to know the status of Public HealthExpenditure in Hyderabad Karnataka region and analyse the deterministic relation between HK-region's Gross Domestic Income and Public HealthExpenditure. The study is conducted based on secondary data; analysis is done by using basic statistics and inference drawn upon OLS regression analysis. The percentage public expenditure to RGDP on health is less than 1\%, which is not an acceptable indication and considered to be robust hurdle in the process of human capital formation of this region. The region is showing the positive trend in regional domestic income; hence government has leverage to spend more on healthsector.

JEL Code: D61; 118

Key words: Public Health Expenditure, Regional Gross Domestic Income, Percapita public expenditure.

\section{INTRODUCTION}

Health is the key component in human capital formation of the nation, thiselementplays significant role in transforming productive and efficient individual and society. World Health Organisation termed health as "state of complete physical, mental and social wellbeing and not merely the absence of disease or infirmity'. Health and development of the nation are interdependent and positively correlated. Social and economic facet of human development is insignificant without health. Hence health is capital, to raise capital, investment on it is vital. So, public expenditure on health sector is investment in the process of human capital formation. Public investment on health is obligatory in nature for human development.

Health is the indicator of status of life i.e., key indicator of quality of life. World health organisation stressed this at many platforms and directing all the member countries to spend as much as possible percentage to GDP. Indian health sector is open for private people, which is obvious profit is the prime motto. Hence government must play impartial role in bringing better health status by spending much through federal budgetary mechanism. Health is in state list, but union government is not expected to averse the responsibility; however two tier system of government executing their part of responsibility.

Across the globe there are great variations on the amount countries spend on health. Health expenditure with respect to economic development, some countries spend more than $12 \%$ of GDP on health, while others spend less than $3 \%$, on health. ${ }^{1}$

Health status is the outcome of public spending; Public income is the result of better health standards in the society. Both influences and complements each other growth, we can infer the relationship in the study by finding out deterministic relationship between Public Heath Expenditure and Gross District Domestic Product.

\section{REVIEW OF LITERATURE}

Adolph Wagner (1883), the German economist made an in depth study on government expenditure in the late 19thcentury. Based on the study, he propounded a law called "The Law of Increasing State Activity". Wagner's law states that "as the economy develops over time, the activities and functions of the government increase".

\footnotetext{
${ }^{1}$ The Determinants of Health Expenditure: A Country-Level Panel Data Analysis. WHO Working paper 2011
} 
Musgrave (1969)expressed a view that the growth of public expenditure might be related to the pattern of economic growth and development in societies. The considerable amount of public expenditure is required on social overhead capital, where private investment is inadequate to finance this necessary expenditure.

Dadibhavi, (1991)examined the inequalities in Education and Health, which have resulted in regional imbalance in social infrastructure. An improvement in the quality of human factor is essential as investment in physical capital. He concluded that the expenditure on improvement of healthcontribute to productivity by raising the quality of the population and these outlays yield continuing returns in future.

Hooda, (2015) study states that there is high inter- state variation in public expenditure on health across states of India. This study examines the degree to which this discrepancy in health expenditure is explained by income and other socio- economic- demographic factors.

Cited in Kesavarajah, Mayandy (2012) Peacock and Wiseman used the following double log equation to estimate the elasticity. According to them, growth in real government expenditure (RGE) is dependent upon the growth in real GDP. We have

$\ln \mathrm{RGEt}=\mathrm{a}+\mathrm{b} \ln (\mathrm{RGDPt})+\mathrm{ut}$.

\section{OBJECTIVES OF THE STUDY}

$>$ To trace the pattern of HK region's Gross Domestic Income

$>$ To know the status of Public Health Expenditure in HK- region

$>$ To analyse the deterministic relation between HK-region's Gross Domestic Income and Public Health Expenditure.

\section{SCOPE AND LIMITATIONS OF THE STUDY}

The present study focuses on six districts of North Karnataka, which is termed as Hyderabad-Karnataka region (HK Region Hereafter), i.e., Ballari, Bidar, Kalaburgi, Koppal, Raichur and Yadagiri. Public Health Expenditure and GDDP details obtained from various reports and open source public information by the state government websites. The scope of the study covers the Public Health expenditure of the six districts of HK region. Region Gross Domestic Product is only considered (calculated based on six districts GDDP). Percapita expenditure on health is based on 2001 and 2011 census population data.Limitation of the study is the public expenditure on health by union and state government through direct disbursement if any, which are not channelized through PRIs is not considered.

\section{METHODOLOGY}

The study is based on secondary data, which are collected through open source access of government publications, Directorate of Economics and Statistics website. Analysis and result discussion is done by using OLS regression; graphical presentations are also used to interpret the basic information on trend and composition of RGDP, Health Expenditure and other details. 


\section{DATA ANALYSIS AND RESULT DISCUSSION}

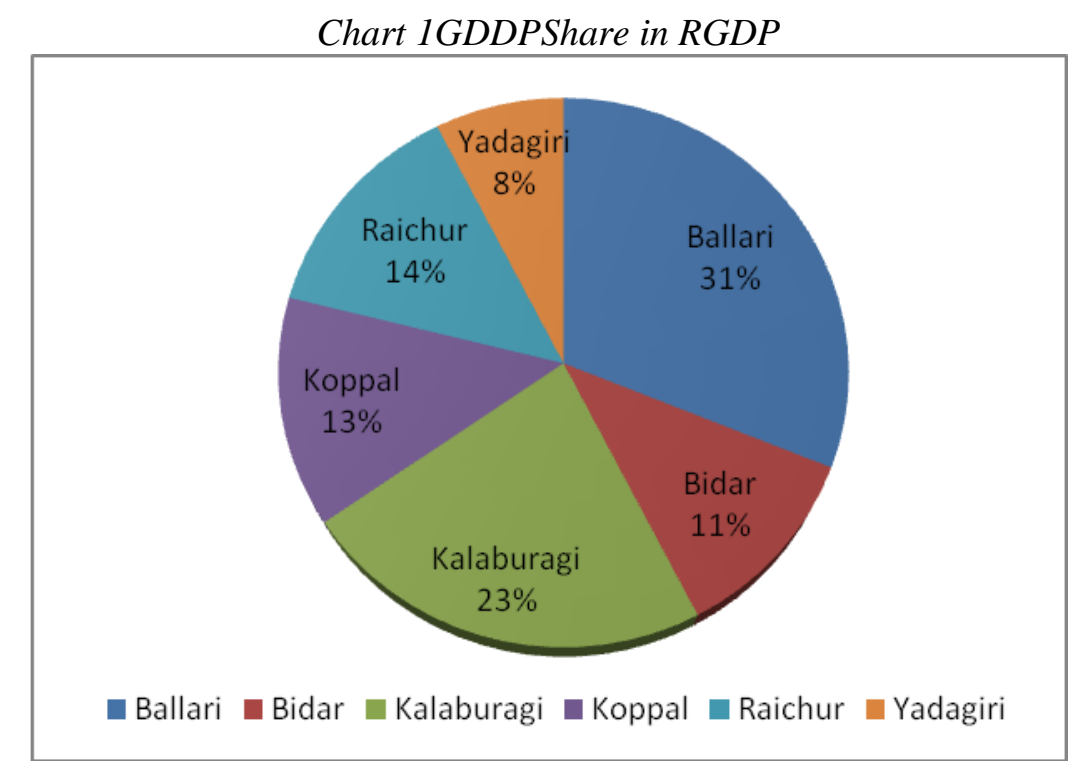

Source: Author's compilation based on information in DES, Bangalore

The chart 1 depicts the share of each district GDP in the RGDP. During the study it was found that Ballari district share to region's gross domestic income is nearly one third of total income. Kalaburgi is the revenue division and political power house of this region is contributing 23 percent to RGDP. Raichur, Koppal and Bidar are contributing more or less in the same proportion. Yadagiri is the newly formed District which is yet to leverage its potency in contribution to HK regions income.

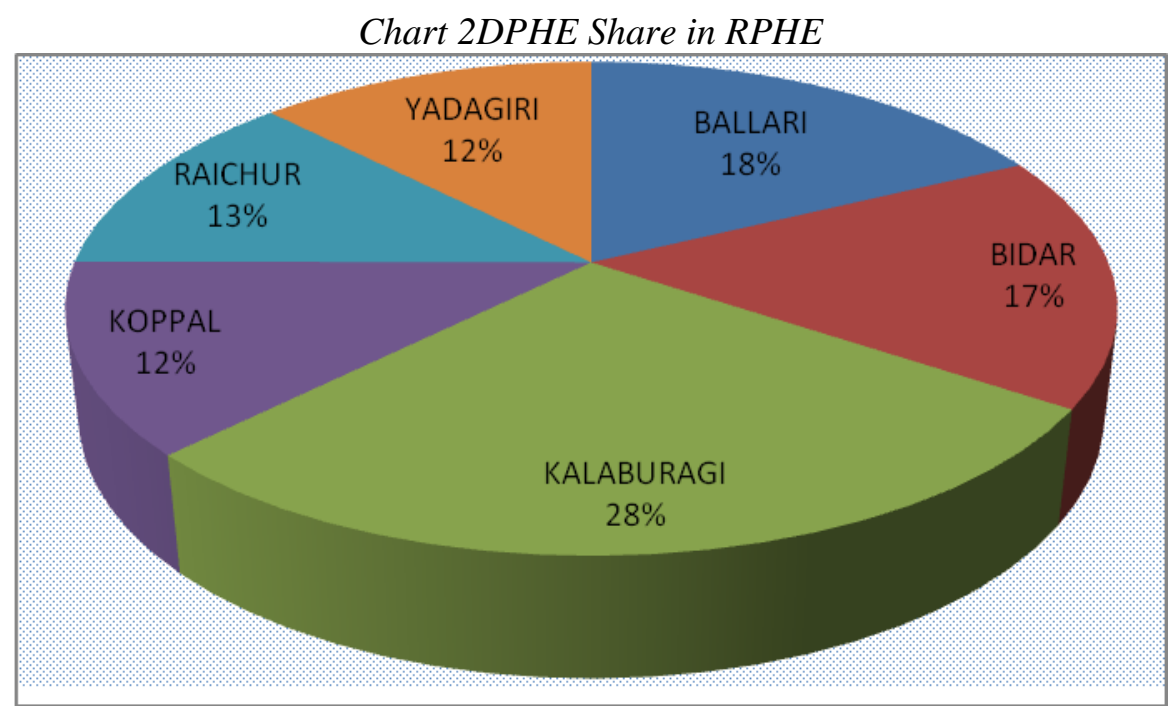

Source: Author's compilation based on Secondary source of information.

The Chart 2 displays the district-wise share in Region's public health expenditure, which reveals the other side of the regions feature. Kalaburgi is the major beneficiary of public health expenditure disbursement. Its contribution to RGDP is 23 percent but share in expenditure is 28 percent, whereas Ballari district contribution to RGDP is 31 percent but share in expenditure is merely 18 percent. This challenges the 
researcher's intention of finding relation between District Domestic income and District public health expenditure. The other districts of the region are getting their pie in the expenditure near proportion to their District Domestic income.

\section{HK region Trend in RGDP}

The Hyderabad Karnataka region is less developed compare to rest of the state. Prof. D. M. Nanjundappa committee, using 35 indicators, categorised the 175 taluks of the state into 39 most backward taluks, 40 more backward taluks and 35 backward taluks. The committee found that north Karnataka region was backward in general and Hyderabad-Karnataka in particular as more backward. ${ }^{2}$ Out of 39 most backward taluks, Gulbarga division had 21 taluks. This number made the researcher to link the RGDP to Public Health expenditure (Health is an important indicator in defining development).

Regional Gross Domestic Product of Hyderabad-Karnataka region is calculated based on District Gross Domestic Product data compiled by the Directorate of Economics and Statistics, Bangalore. The present study focuses on 2004-05 to 2012-13 periods for calculation of RGDP. Chart 3 reveals that HK RGDP was Rs. $22656.53 \mathrm{Cr}$. in 2004-05, which has increased to Rs. $27547.46 \mathrm{Cr}$. in 2008-09. This number stood at Rs.37526.68 Cr. in 2012-13. RGDP is annually increasing at an average of Rs. 28774.49 and average Regional Growth rate is 6.13 .

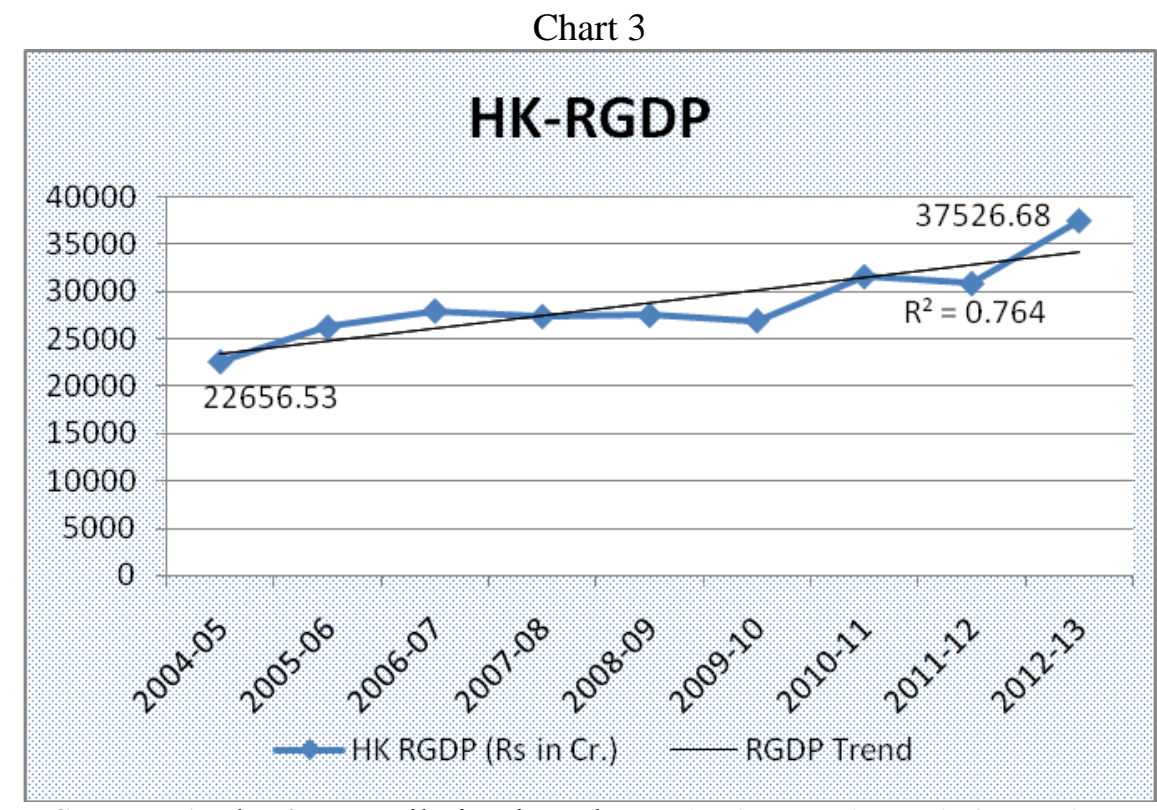

Source: Author's compilation based on District at Glance information.

\section{HK region Trend in public health expenditure}

The public health expenditure of HK region is showing increasing trend. The public expenditure on health is compiled under government heads of account 2210 and 2211 which are medical, public health and family welfare expenditure respectively.

${ }^{2}$ High power committee for redressal of regional imbalances-2002 
Chart 4

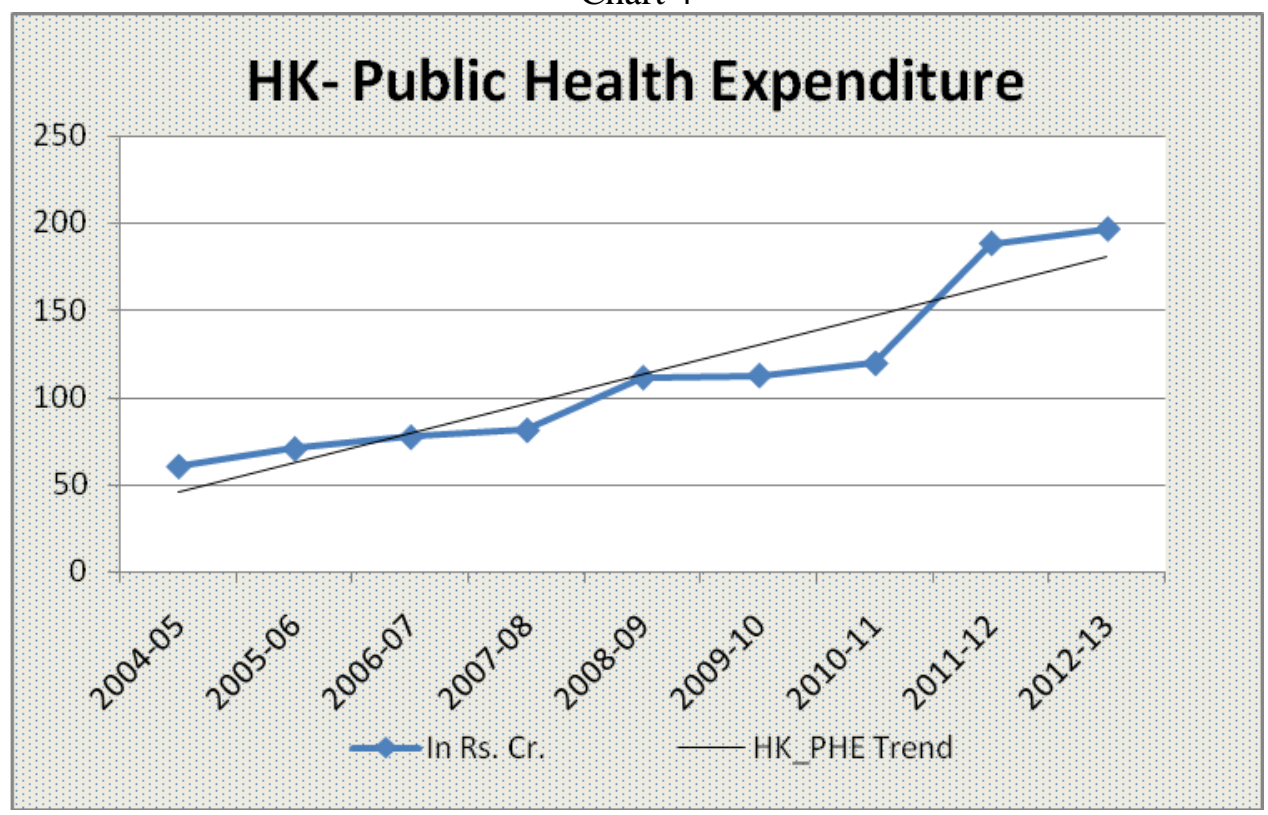

Source: Author's compilation based on Secondary source of information.

In 2004-05 Rs.60.36 cr. spent on this purpose, which was increased to Rs.111.18 cr. in 2008-09 and further in 2012-13 this number stood at Rs.196.22 crores. Amount spent on public health sector seems to be sound but is inadequate in relation to this region gross domestic income and per capita expenditure on health which is explained in the next chapter.

Chart 5

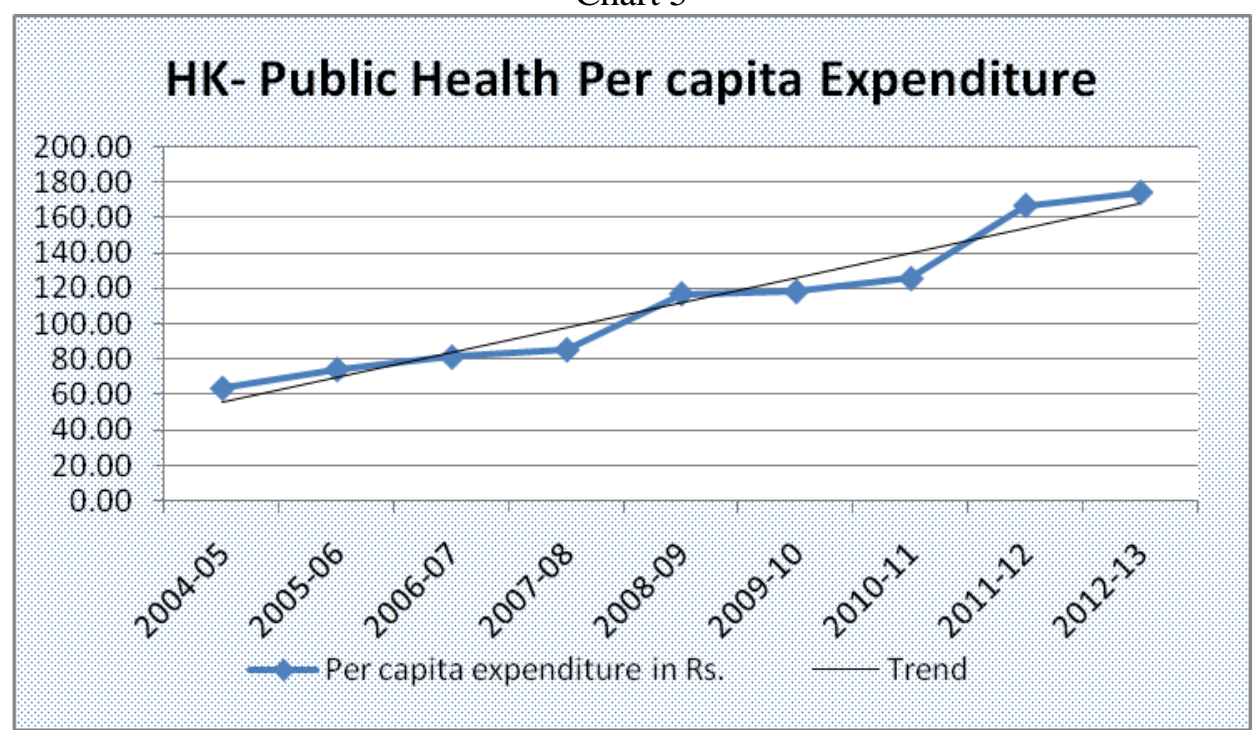

Source: Author's compilation based on Secondary source of information.

The public health expenditure in HK region is increasing and in less than decade period it has increased from Rs. $60 \mathrm{Cr}$ to Rs. $196 \mathrm{Cr}$. which seems to be significant. However percapita expenditure on health reveals other side of the coin. Per head annual public expenditure on health in 2004-05 was Rs. 63.36, which is nothing but token alotment. This figure rised to Rs. 116.71 in 2008-09 and further to Rs. 173.86 in 2012-13. It reveals the dismal condition of the HK region. The private health sector is concentrated its function on old mysore and canara belt of the state, and HK region is untapped due to various operational 
challenges of private health service providers. It is the government's duty and obligation to provide health facility to this region, but the above percapita expenditure data shows negligent act in allotting adequate resource in par with growing population.

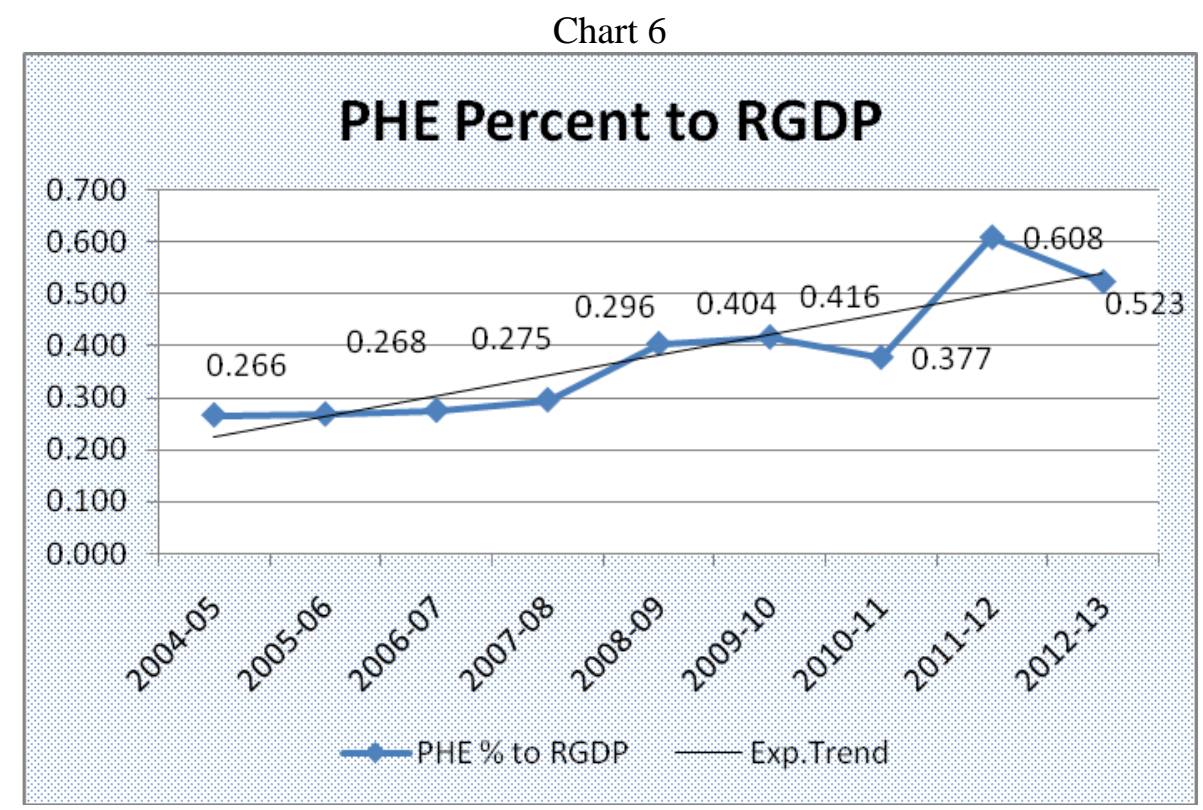

Source: Author's compilation based on Secondary source of information.

Karnataka has made significant progress in improving the health status of its people in the last few decades. However, despite the progress, the State has a long way to go in achieving the desired health goals. State public expenditure on Health is about $0.9 \%$ of GSDP during the 11th plan period ${ }^{3}$. But the Public Health Expenditure in HK region is less than 0.6\% of RGDP (except for the period 2011-12). This shows the clear disparity in state Public Health expenditure and HK region's magnitude of disbursement. In 2004-05 PHE percent to RGDP was mere 0.26, this figure continued till 2008-09. In 2011-12 this number showed positive sign, increased to 0.6.

\section{EMPIRICAL RELATIONSHIP BETWEEN RGDDP AND HK-PHE}

To test the empirical relationship between RGDDP and HK-PHE researcher used the OLS Regression model.

\section{$\mathrm{PHE}=\beta_{0}+\beta_{1} \mathrm{RGDP}+v$}

Where, PHE is Public Health Expenditure; RGDP is Regional Gross Domestic Product; u error term, $\beta_{0}$ and $\beta_{1}$ are tangentand slope constants.

Literature survey reveals that Public health expenditure depends upon its gross domestic income, in the present study researcher tried to know the Regional-GDP impact on region's total health expenditure. In the above regression model PHE indicates the HK regions public health expenditure (summation of six districts Public Expenditure on Medical, Public Health and Family welfare, mentioned in PE Heads of Account 2210 and 2211), $\beta_{0}$ and $\beta_{1}$ are constant and coefficient of determination, RGDP is HK regions Gross Domestic Product (which is again Summation of six districts GDDP), and verror term of the model,

\footnotetext{
${ }^{3}$ Economic Survey of Karnataka 2015-16
} 
which shows the magnitude of impact on PHE other than RGDP. $\beta_{1}$ explains the extent of RGDP affects the HK-PHE.

Result Table -1

Model 1: OLS, using observations 2005-2013 (T = 9)

Dependent variable: HK-PHE

\begin{tabular}{|l|c|c|c|c|l|}
\hline & Coefficient & Std. Error & t-ratio & $p$-value & \\
\hline Const & -176.463 & 67.6531 & -2.6084 & 0.0350 & $* *$ \\
\hline HK-RGDP & 0.0100565 & 0.00232937 & 4.3173 & 0.0035 & $* * *$ \\
\hline
\end{tabular}

\begin{tabular}{|l|r|l|l|r|}
\hline Mean dependent var & 112.9081 & & S.D. dependent var & 49.33828 \\
\hline Sum squared resid & 5316.889 & & S.E. of regression & 27.56004 \\
\hline R-squared & $\mathbf{0 . 7 2 6 9 7 7}$ & & Adjusted R-squared & 0.687973 \\
\hline F $(1,7)$ & 18.63884 & & P-value(F) & 0.003492 \\
\hline
\end{tabular}

The model coefficient shows that one unit increase in independent variable, the dependent variable increases by 0.10 percent, which means Rs. 1 crore increase in RGDP influences the HK-PHE to Rs. 10 lakhs. However, only coefficient value will not determine the relation. Hence $\mathrm{R}^{2}$, P-values and $\mathrm{t}$ stat together explains the relation between independent and dependent variable better.

Result Table1 shows the regression analysis; where $\mathrm{R}^{2}$ is 0.726 , it means $72.69 \%$ variation in HK-PHE is explained by RGDP, obtained p-values are statistically significant, so there is a positive relationship between RGDP and the HK-PHE. Independent variable, HK-RGDP appears to be significant at 1percent level of significance, and intercept is also significant at 5 percent level of significance.

\section{SUMMARY AND CONCLUSION}

The present study focuses on Health expenditure in HK region and it is found that there is increasing trend in budgetary provisions for Public health expenditure. But it is meager to compare its own regions gross domestic income. The percentage public expenditure to RGDP on health is less than $0.3 \%$ is found for the first half of decade, which was slightly improved to $0.6 \%$ in the year 2011-12 but overall still it is less than $1 \%$, which is not an acceptable indication and considered to be robust hurdle in the process of human capital formation of this region. As this region is known for malnutrition, high maternity and infant mortality rate in the state, budgetary provision for Public health expenditure must be increased to ensure the right to get healthy state of life. The region is showing the positive trend in regional domestic income; hence government has leverage to spend more on health sector which is need of the hour, ever.

\section{REFERENCES}

1. Amiri and Ventelou, B. (2012), Granger causality between total expenditure on health and GDP in OECD: Evidence from the Toda-Yamamoto approach. Economics Letters, 116(3), 541-544.

2. Annigeri, Kulkarni and Revankar (2016), Evaluation of Regional Development Boards of Karnataka, CMDR Monograph Series No-77, Centre for Multi-Disciplinary Development Research (CMDR), Dharwad.

3. Dadibhavi, R. V. (1991). Disparities in Social-Infrastructure Development in India" between years of 1970-71 to 1984-85". The Asian Economic Review, Vol. 33 (1), April, 31-48.

4. Hooda, S. K. (January 2015). Determinants of Public Expenditure on Health In India: The Panel Data Estimates,. Working Paper 177, Institute for Studies in Industrial Development New Delhi.

5. Kesavarajah, M. (2012). Wagner's Law in Sri Lanka: An Econometric Analysis. International Scholarly Research Network. 
6. Kurian, N.J. (2000), Widening regional disparities in India: Some Indicators, Economic and Political Weekly, February 12, pp. 538-550.

7. Prof. Nanjundappa Report of the High Power Committee for Redressal of Regional Imbalances in Karnataka, (2002)

8. Shiddalingaswami and Raghavendra (2010), Regional Disparities In Karnataka: A District Level Analysis Of Growth And Development. CMDR Monograph Series No-60, Centre for MultiDisciplinary Development Research (CMDR), Dharwad.

9. Shiddu and Aziz (2012), District Level Development Disparities In Karnataka, CMDR Monograph Series No-68, Centre for Multi-Disciplinary Development Research (CMDR), Dharwad.

10. State and District Domestic Product of Karnataka (2014-15), Directorate of Economics and Statistics, Bangalore. 